\title{
ValpoScholar
}

Valparaiso University Law Review

Volume 36

Number 3 Summer 2002

pp.631-654

\section{Summer 2002}

\section{The Rule That Isn't a Rule - The Business Judgment Rule}

Douglas M. Branson

Follow this and additional works at: https://scholar.valpo.edu/vulr

Part of the Law Commons

\section{Recommended Citation}

Douglas M. Branson, The Rule That Isn't a Rule - The Business Judgment Rule, 36 Val. U. L. Rev. 631 (2002).

Available at: https://scholar.valpo.edu/vulr/vol36/iss3/3

This Lecture is brought to you for free and open access by the Valparaiso University Law School at ValpoScholar. It has been accepted for inclusion in Valparaiso

University Law Review by an authorized administrator of ValpoScholar. For more information, please contact a ValpoScholar staff member at scholar@valpo.edu. 


\title{
The Indiana Supreme Court Lecture:
}

\section{THE RULE THAT ISN'T A RULE - THE BUSINESS JUDGMENT RULE}

\author{
Douglas M. Branson*
}

\section{INTRODUCTION}

The much misunderstood business judgment rule is not a "rule" at all. It has no mandatory content. It involves no substantive "do' $s$ " or "don' ts" for corporate directors or officers. Instead, it is a standard of judicial review, entailing only slight review of business decisions. Alternatively, it could be called a standard of non-review, entailing no review of the merits of a business decision corporate officials have made. ${ }^{1}$

Various commentators' comments to the contrary, mostly based upon one celebrated (or lamented) Delaware decision, ${ }^{2}$ strictly speaking, the standard of care applicable to corporate directors remains due care. As the Model Business Corporation Act and the Indiana statute phrase it, a director is to discharge her duties "with the care an ordinarily reasonably prudent person in a like position would exercise under similar circumstances." 3 The standard of conduct is not "slight care," or "gross negligence," or anything other than due care.4

\footnotetext{
-W. Edward Sell Chair in Law, University of Pittsburgh. B.A., University of Notre Dame; J.D., Northwestern University; LL.M., University of Virginia. This Article is based upon the Indiana Supreme Court Lecture, delivered by the author at Valparaiso University School of Law on September $20, \mathbf{2 0 0}$. The author thanks the Supreme Court of Indiana for the support for legal education evinced by the Supreme Court Lecture program in Indiana's four law schools. The author thanks Justices Frank Sullivan, Jr., and Robert D. Rucker for attending the lecture and for their comments and questions. The author wishes further to thank Dean Jay Conison and Professor Paul H. Brietzke for hospitality that exceeded all expectations.

1 See generally DOUGLas M. BRANSON, CORPORATE GOVERNANCE $\$ \$$ 7.01-7.20 (1993).

2 Smith v. Van Gorkom, 488 A.2d 858 (Del. 1985) (discussed further throughout).

${ }^{3}$ Rev. MODEl BUS. CORP. ACT $\$ 8.30$ (1984) (hereinafter RMBCA); IND. CODE \& 23-1-35-1 (1989).

4 See, e.g., Theroit v. Bourg, 691 So. 2d 213, 222 (La. Ct. App. 1997) (concluding that "the applicable standard is that set forth by the plain language" of Louisiana's version of RMBCA $\$ 8.30$, and that adoption of a gross negligence standard would amount to 


\section{2 VALPARAISO UNIVERSITY LAW REVIEW [Vol. 36}

But who cares? Many do, because in the modern era the number of temporal occasions at which the business rule ex ante becomes the yardstick for directors in shaping their decision-making processes, or $e x$ post the yardstick by which courts and litigants review (or do not review) directors' decisions, have multiplied. The uses to which the rule may be put, and the temporal stages at which it may be encountered, either in transactional settings or in litigation, have proliferated, often to the detriment of those who would be critical of corporate conduct.

The business judgment rule is multi-faceted. Most generally, the business judgment rule acts as a presumption in favor of corporate managers' actions. Stronger still, the rule provides a safe harbor that makes both directors and their actions unassailable if certain prerequisites have been met. In litigation, the rule is a means for conserving judicial resources, thereby permitting courts to avoid being mired down in rehashing decisions that are inherently subjective and ill suited for judges, as opposed to business men and women. Last of all, the rule is the law's implementation of broad economic policy, built upon economic freedom and the encouragement of informed risk taking.

Newer uses to which the business judgment rule may be put include the means by which boards of directors adopt takeover defenses and by which, after the fact, courts review the adoption of those defenses when disgruntled shareholders pursue litigation. Another newer use is as a means by which corporations and their attorneys evaluate and, based upon that evaluation, recommend that courts dismiss derivative litigation.

Yet another use to which the business judgment rule may be put is as a teaching tool. I impress upon law students their future roles as "process engineers." By placing a premium upon the process that directors follow to reach a decision, rather than the resulting decision itself, the business judgment rule serves as a vibrant illustration of process engineering and the attorney's role in it. Moreover, the business judgment rule and the roles it may play are not limited to the corporate boardroom. The business judgment rule and good process are a part of "institutions law," useful to the attorney advising a

\footnotetext{
"impermissible judicial negation of the legislature's acts"); Stuart R. Cohn, Demise of the Director's Duty of Care: Judicial Avoidance of Standards and Sanctions Through the Business Judgment Rule, 62 TEX. L. REv. 591, 604, 617-23 (1983) (lamenting courts' and commentators' proclivity fully to collapse the standard of conduct into the business judgment rule).
} 
neighborhood association, a PTA, or a faculty or faculty committee, as well as a corporation' $s$ board of directors.

Apropos of the business judgment rule's currency, prior to 1990 no Indiana decision parsed the business judgment rule. 5 Subsequent to 1990 , no less than four Indiana appellate court decisions have dealt with various elements of the rule. 6 And, except for Delaware, the Indiana experience would be representative of the experience in most of the incorporating jurisdictions in the United States.

One last curiosity to be noted before delving into the rule itself is that, despite the vastly increased invocations of the rule in the modern era, the business judgment rule remains uncodified. With one exception, it is purely a product of judge-made law? It also remains an exclusively American legal construct, again with one exception. The exception is Australia, which, in 1999, based upon a well-known United States formulation of the rule, ${ }^{8}$ enacted the first, and to this author's knowledge, the only, statutory version of the business judgment rule.9

Without further salutation, then, the time has come for more closely examining the business judgment rule and parsing its elements.

\footnotetext{
5 Westlaw Search, IN Database, September 14, 2001, on file with the Valparaiso University Law Review.

6 See G \& N Aircraft v. Boehm, 743 N.E.2d 227 (Ind. 2001); Cutshall v. Barker, 733 N.E.2d 973 (Ind. Ct. App. 2000); Brane v. Roth, 590 N.E.2d 587 (Ind. Ct. App. 1992); Krukemeier v. Krukemeier Mach. \& Tool Co., 551 N.E.2d 885 (Ind. Ct. App. 1990).

7 The statutory codification of the standard of conduct, as in RMBCA $\$ 8.30$, is not the business judgment rule, as the RMBCA commentary makes clear:

The elements of the business judgment rule and the circumstances for its application are continuing to be developed by the courts. Section 8.30 does not try to codify the business judgment rule or to delineate the differences between that defensive rule and the section's standards of director conduct. Section 8.30 deals only with standards of conduct - the level of performance expected of every director ...
}

3 MODEL BUS. CORP. ACT ANN., $\$ 8.30$ official cmt., 8-161, at 8-163 (3d ed. 1984) (Supp. 1999). Nonetheless, at least two Indiana cases read the Indiana standard of conduct, IND. CODE \$ 23-1-35-1 (a) \& (b), or the limitation of director liability for damages, IND. CODE \$ 23-1-351(e), which is based upon the Revised Model Act language, as a legislative codification of the business judgment rule. See $G \& N$ Aircraft, 743 N.E.2d at 239; Krukemeier, 551 N.E.2d at 888.

8 AMERICAN LAW INSTTIUTE, PRINCIPLES OF CORPORATE GOVERNANCE: ANALYSIS AND RECOMMENDATIONS § 4.01(c) (1994) (hereinafter ALI CORP. GOV. PROI.).

' See AUSTRALIAN CORPORATIONS ACt \$ 180(2) (1999) ("Business judgment rule"). 


\section{VALPARAISO UNIVERSITY LAW REVIEW [Vol. 36}

II. DO NOT CONFUSE POLICY BASES OR THE EFFECT OF THE RULE WITH THE RULE ITSELF

Courts are among the major perpetrators of this common error. "Courts," one venerable court stated, will not review "an honest mistake of business judgment." 10 This economium is a statement of the result of the rule, not the rule itself.

A similar statement is that "[d]irectors of a commercial corporation may take chances, the same kind of chances that a man would take in his own business." 11 This statement describes more a policy basis for the rule rather than the rule itself, or the rule stated in any helpful analytical way.

Yet another court recited, in a manner similar to the venerable court first quoted above: "[o]rdinarily neither the directors nor the other officers of a corporation are liable for mere mistakes or errors of judgment."12

\section{COMMON FORMULATIONS OF THE RULE}

There are really only two formulations of the rule with wide currency: the Delaware business judgment rule and the American Law Institute (ALI) formulation.

Although not without its critics, ${ }^{13}$ the ALI formulation seems to be a good one and has been adopted by the highest courts of several states. ${ }^{14}$ It states:

(c) A director or officer who makes a business judgment in good faith fulfills the [duty of care] if the director or officer:

(1) is not interested in the subject of his business judgment;

\footnotetext{
10 Bodell v. Gen. Gas \& Elec., 140 A. 264, 267 (Del. 1927).

" Ski Roundtop, Inc. v. Hall, 658 P.2d 1071, 1078 (Mont. 1983).

12 Nursing Home Bldg. Corp. v. DeHart, 535 P.2d 137, 143-44 (Wash. Ct. App. 1975).

13 See, e.g., William J. Camey, Section 4.01 of the American Law Institute's Corporate Governance Project: Restatement or Misstatement?, 66 WASH. U. L.Q. 239, 271-88 (1988).

1+ See, e.g., Rosenfield v. Metals Selling Corp., 643 A.2d 1253, 1261 (Conn. 1994); Omnibank v. United S. Bank, 607 So. 2d 76, 85 (Miss. 1992); Cuker v. Mikalauskas, 692 A.2d 1042, 104546 (Pa. 1997).
} 
(2) is informed with respect to the subject of the business judgment to the extent the director or officer reasonably believes to be appropriate under the circumstances; and

(3) rationally believes that the business judgment is in the best interests of the corporation. ${ }^{15}$

In shorthand, a director and her decision are protected from legal attack if: first, she and her colleagues made a judgment or decision; second, the decision makers were free from disabling conflicts of interest; third, they exercised some (not necessarily reasonable) care in informing themselves about the matter decided; and fourth, they had a rational (not necessarily reasonable) basis for the decision they made.

One function of the rule is as a conservator of judicial resources. If the rule required "reasonable" care or a "reasonable" basis for every decision, courts would have to hold plenary hearings (trials) because it is in those fora that questions of reasonableness are decided. The rule would not serve its function. Instead, if other prerequisites are present (proactive directors making a decision, freedom from conflicts of interest, and so on), the defending directors need demonstrate only some (slight) care and only a rational (plausible) basis for the decision made.

Delaware courts state the rule more succinctly and in the language of a "presumption." Thus, the business judgment rule is "a presumption that in making a business decision the directors of a corporation acted on an informed basis, in good faith and in the honest belief that the action taken was in the best interests of the company." 16

Delaware courts look for the same elements as do other courts: a judgment or decision, some care, and good faith (absence of conflicts of interest or base motive). The difference is, because of the use of presumption, in Delaware, a plaintiff shareholder has the burden of going forward. The challenging shareholder must demonstrate that the collegial body (the board) was infected by conflicts of interests on the part of a critical group (although perhaps less than a majority) of

\footnotetext{
${ }^{15}$ ALI CORP. Gov. PROJ., supra note 8, $\$ 4.01$ (c).

16 Aronson v. Lewis, 473 A.2d 805, 812 (Del. 1984). The Aronson court's statement of the rule is the one most quoted by Delaware courts, eclipsing the earlier precedent of Warshow v. Calhoun, 221 A.2d 487, 492-93 (Del. 1966), which contained similar, but not identical, phrasing.
} 


\section{VALPARAISO UNIVERSITY LAW REVIEW [Vol. 36}

directors.17 Or the shareholder might offer credible proof that the directors merely rubber-stamped the Chief Executive Officer's (CEO's) decision, and thus had not made a judgment or decision of their own.18

By contrast, the ALI version is a safe harbor. The directors have the burden of establishing the presence of the rule' s elements. Once they do so, however, the payoff is greater. The director will have sailed into an impregnable harbor. On the other hand, presumptions may be upset, meaning perhaps that the directors will have to go through the ordeal of a trial in order to vindicate themselves. ${ }^{19}$

There are outlier formulations here and there. In the late 1980s and early 1990s, when seemingly every savings and loan in Texas had failed and all of their directors were being sued, Texas courts used the business judgment rule to protect those directors: "Texas courts to this day will not impose liability upon a non-interested corporate director unless the challenged transaction is ultra vires or tainted by fraud... Such is the business judgment rule in Texas." 20 Such a statement has two faults. One is that it seems to be another statement of the result of the rule, rather than the rule itself. A second is that it protects directors who did nothing. More astute courts recognize that the business judgment rule does not protect complete absences of care. Directors completely asleep at the switch do not enjoy the rule's protection. ${ }^{21}$ They must go to trial

\footnotetext{
17 Cede \& Co. v. Techricolor, Inc., 634 A.2d 345, 363-65 (Del. 1993) (noting that the factual question is how much self-dealing or other conflicts taint "the collective independence of the board").

18 See, e.8., Smith v. Van Gorkom, 488 A.2d 858 (Del. 1985) (finding breach of duty where the directors made decision to sell company after two-hour meeting, called on short notice with no documents or written analyses whatsoever, rubber-stamping the decision of an aged CEO who wanted to sell the company and retire).

${ }_{19}$ See infra notes 50-57 and accompanying text (comparing presumptions versus safe harbors). At least two of the four recent Indiana decisions cite and rely on the Delaware cases, especially Aronson v. Lewis, 473 A.2d 805 (Del. 1984), and the business judgment rule as a presumption analysis. See also G \& N Aircraft v. Boehm, 743 N.E.2d 227, 238 (Ind. 2001); Brane v. Roth, 590 N.E.2d 587, 591-92 (Ind. Ct. App. 1992).

20 Resolution Trust Co. v. Norris, 830 F. Supp. 351, 356 (S.D. Tex. 1993) (quoting Gearhart Indus. v. Smith Int'1, 741 F.2d 707, 721 (5th Cir. 1984)); see also FDIC v. Brown, 812 F. Supp. 722, 724 (S.D. Tex. 1992).

21 Statutes in Virginia, Wisconsin, and Indiana modify the standard of conduct itself, providing that the director with a warm heart but empty head cannot be held liable. See, e.8., IND. CODE \$23-1-35-1(e) (1989) (no money damage liability for directors unless found to have engaged in "willful misconduct or recklessness"); WISC. STAT. ANN. \$180.307 (West Supp. 2001) (similar). In Brane, the Indiana Court of Appeals held that the modified standard should not be applied retroactively, affirming liability of directors of a grain elevator for their complete failure to hedge grain purchases by futures transactions. 590 N.E.2d at 590.
} 
where they will have to establish that they exercised not only some care, but due care.

\section{FURTHER POLICY BASES FOR THE RULE}

The "good" governance movement of the last fifteen or so years contemplates a board comprised of a super majority of truly independent directors, that is, non-insiders who are free of any significant financial or even social ties to the senior executives.22 Today, even traditional candidates for board service, such as the trusted outside lawyer, investment banking firm partner, or commercial banker, are considered non-independent and are becoming a rarity of sorts on boards of directors.

The business judgment rule now more than ever is necessary to encourage truly independent persons to serve as directors. APersons of reason, intellect and integrity would not serve if the law exacted from them a degree of prescience not possessed by others." 23 Once on the board, a strong business judgment rule is necessary to encourage those independent directors to engage in the type of informed risk taking that is essential to business success.

Returning to the judicial point of view, courts are ill-equipped to review business decisions. Those decisions often involve intangibles, intuitive insights or surmises as to business matters such as competitive outlook, cost structure, and economic and industry trends. Business decisions often come down to matters of touch and feel not susceptible to systematic analysis.

Courts may also buttress their non-involvement with a statutory argument. Corporate statutes universally provide that it is the board of directors, and not the court, who is to manage or supervise the management of the corporation' $s$ business and affairs. ${ }^{24}$

Last of all, as previously mentioned, a policy behind the rule is conservation of the judicial resource. The business judgment rule is a

\footnotetext{
22 See, e.g., Douglas M. Branson, Corporate Governance "Reform" and the New Corporate Social Responsibility, 62 U. PrrT. L. REV. 605, 627 (2001) (describing "good governance movement"). 23 Samuel Arsht, The Business Judgment Rule Revisited, 8 HOFSTRA L. REV. 93,97 (1979).

${ }^{24}$ See, e.g., RMBCA, supra note 3, \$8.01 ("All corporate powers shall be exercised by or under the authority of, and the business and affairs of the corporation managed under the direction of, [the] board of directors ....").
} 
filter that enables courts to easily screen out non-meritorious challenges to the actions of directors and executives.

\section{RELATIONSHIP TO THE STANDARD OF CONDUCT}

The standard of conduct is due care. It is not slight care or gross negligence. With that established, the business judgment rule may be the de facto standard of conduct in cases in which directors are proactive, making a judgment or decision, that may be a deliberative decision to take no action, as opposed to cases of complete nonfeasance.

The last policy reason leads nicely to a hypothetical showing how the rule and the standard of conduct might play off one another. After a shareholder suit is filed, the directors and the corporation might file a motion for summary judgment. They could attach thereto an affidavit by the Chief Financial Officer stating that she had prepared and distributed a written report on the pros and cons of the decision to be made, an affidavit by a director stating that the board met and received an oral report from another senior executive or outside consultant, and a copy of the board resolution, certified by the corporate secretary as a true and correct copy of the resolution contained in the minutes of the board meeting. The court would examine such affidavit evidence. The business judgment rule requires only some care, so the court need not review the decision-making process on a plenary basis. The court might then grant the defense motion.

Suppose, however, that the plaintiff alleges with particularity why a critical mass of directors had an interest in the subject matter of the board decision. In that case, the court would deny the defense motion for summary judgment.

Loss of the motion, however, does not translate into perdition for the directors or their decision. It means merely that the judge will hold the case over for trial. At trial, the defendant directors might assert again the business judgment rule defense, although the judge may say that the court's earlier ruling is the law of the case on that score. Then the directors would ask that the decision-making process be reviewed on a plenary basis because they contend that they have met the standard of conduct, that is, they exercised not only some care but due care. They may also assert other defenses, such as a lack of causation, a superceding 
cause, $^{25}$ or that the corporation had suffered no legally cognizable damage. ${ }^{26}$

\section{COMPONENTS OF THE RULE - THERE MUST HAVE BEen a DECISION OR JUDGMENT}

Sometimes it is said that there must be an independent judgment or decision. Rubber-stamping the CEO's or controlling shareholder's wish or command will not do. One of the classic cases involved a shareholder contention that, when the directors of the Chicago Cubs baseball club voted to uphold majority owner P.K. Wrigley's decision to have no lights and therefore no night baseball, those directors were merely implementing Wrigley's inveterate belief that God meant baseball to be a game played in the daytime. According to the plaintiff minority shareholder, the reasoning given by the directors - that night baseball would ruin the neighborhood surrounding Wrigley Field - was pretextual. ${ }^{2}$ Nonetheless, the Illinois court afforded business judgment rule protection to the Chicago Cubs' board of directors and its decision.

A decision to make no decision is also a judgment or decision for purposes of the rule's application. ${ }^{28}$ Veteran directors, though, say that boards often act by consensus and that consensus builds by a process of accretion. A requirement that matters be put to motions and votes encourages confrontation. It forces boards to act like legislative bodies or, worse yet, like faculty meetings at colleges and universities.

The business judgment rule's emphasis on the process leading to formal judgments also constitutes make-work for lawyers who, as process engineers, come to have a larger role than they should have in the board room. Similarly, critics of the modern business judgment rule say that insistence on formal decisions places a premium on play acting

\footnotetext{
${ }^{25}$ See, e.g., BRANSON, supra note 1, \$\$ 6.11-6.14 (1993).

2o Id.\$6.14.

2 Shlensky v. Wrigley, 237 N.E.2d 776 (IIl. Ct. App. 1968); see also McMullin v. Beran, 765 A.2d 910, 916-20, 924 (Del. 2000) (finding that directors of subsidiary were not entitled to business judgment rule protection because they delegated their decision to a parent corporation when they themselves "had an ultimate statutory duty and fiduciary responsibility to make an informed and independent decision"); Miller v Schreyer, 683 N.Y.S.2d 51, 54 (N.Y. App. Div. 1999) (explaining that "where the wrong alleged is inaction of the board rather than a conscious decision ... the business judgment rule is inapplicable").

${ }^{23}$ See, e.g., Brane v. Roth, 590 N.E.2d 587, 592 (Ind. Ct. App. 1992) ("[T] he rule does not protect directors who have abdicated their position or absent a conscious decision, failed to act.").
} 


\section{VALPARAISO UNIVERSITY LAWREVIEW [Vol. 36}

and on paper trails. It does not improve the quality of decisions that are made.

\section{COMPONENTS OF THE RULE - THE JUDGMENT OR DECISION MUST BE AN} INFORMED ONE

Again, the requirement is some care, not due care. This is what the Supreme Court of Delaware meant in Smith 0 . Von Gorkom ${ }^{29}$ when it stated that "[w]e think the concept of gross negligence is also the proper standard for determining whether a business judgment reached by a board of directors was an informed one." 30 That is, the statement upon which arch-conservative commentators rest their argument that in the modern era, the standard of conduct has changed across the board to gross negligence or slight care, rather than due care. ${ }^{31}$

One noted commentator has urged that the standard to be applied should be a subjective standard. That is, did the directors making the decision reasonably believe that they possessed sufficient information? ${ }^{32}$ An alternative phrasing that asks how much information is enough information, or what information gathering mechanisms (consultants, committees, reports) are sufficient, is itself a matter of business judgment.

A recent judicial pronouncement in Delaware that goes part of the way toward those commentators' urging is that "[ $t]$ he Board is responsible for considering only material facts that are reasonably available, not those that are immaterial or out of the Board's reasonable reach." 33 The court's use of the words "reasonably available" and "reasonable reach" indicate that an objective - rather than wholly subjective standard is still in place.

29488 A.2d 858 (Del. 1985).

30 Smith, 488 A.2d at 873 .

31 One of the most arch of the arch-conservatives has been a St. Louis practitioner, Charles Hansen, who asserted over and over in ALI meetings that the standard of conduct is gross negligence or lower. See, e.g., Charles Hansen, The ALI Corporate Governance Project: Of the Duty of Due Care and the Business Judgment Rule, 41 BUs. LAW. 1237, 1241 (1986).

32 See Joseph Hinsey IV, Business Judgment and the American Law Institute's Corporate Governance Project: The Rule, the Doctrine, and the Reality, 52 GEO. WASH. L. REV. 609, 613-14 (1984).

${ }^{33}$ Brehem v. Eisner, 746 A.2d 244, 259 (Del. 2000), rev'g in part In re The Walt Disney Co. Derivative Litig., 731 A.2d 342 (Del. Ch. 1998). 


\section{COMPONENTS OF THE RULE - ABSENCE OF DISABLING CONFLICTS OF INTEREST}

Conflicts that disable and those that do not are at the antipodes of a spectrum. At the disabling antipode are direct pecuniary interests of the director, her family or associates, or an affiliate of the director, in the judgment or decision for which the rule's protections are sought.

Yet receipt of normal directors' fees, or the desire to retain them, does not disable. In Marx $v$. Akers, ${ }^{34}$ the New York Court of Appeals held that, as a matter of law, the prospect of receipt of future directors' fees in the amount of $\$ 80,000$ per year did not disable IBM's directors from setting those fees. A promise of continuation on the board after a change in control does not disable. Receipt by an investment banking firm of $\$ 229,000$ in annual fees did not disable the firm's partner from sitting on Chevron' $s$ board and participating in a decision in which the firm had rendered advice. ${ }^{35}$ That a director was the former neighbor of a senior executive of the corporation on the other side of a transaction did not disable: conclusionary allegations of "personal affinity" are insufficient to establish director interest of lack of independence. ${ }^{36}$

By contrast, receipt by a director of an undisclosed $\$ 150,000$ finder's fee did disable that director. ${ }^{37}$ The further question, however, was whether the taint of self-interest on the part of some directors infected a decision made by directors who were not disabled.

When a critical mass of directors also wore second hats as well-paid, long term consultants, hired and fired by the controlling shareholder, their decision was held not entitled to business judgment rule protection..$^{38}$ Bank directors who circumvented local banking laws by forming a "competing loan company" were not entitled to the rule's protection for that decision because they accepted management fees from the loan company. 39

Few universal principles may be stated. One may be that so-called structural bias, that is, the predilection of directors to favor those of the same social or economic class, such as fellow directors or senior

\footnotetext{
H 666 N.E.2d 1034 (N.Y. 1996).

35 Katz v. Chevron Corp., 22 Cal. App. 4th 1352, 1368 (1994).

${ }^{36}$ Odyssey Partners v. Fleming Cos., 735 A.2d 386, 409-10 (Del. Ch. 1999).

${ }^{37}$ Cede \& Co. v. Technicolor, Inc., 634 A.2d 345, 362 (Del. 1993).

31 Clark v. Lomas \& Nettleton Fin. Corp., 625 F.2d 49, $52-53$ (5th Cir. 1980).

39 Warren v. Century Bankcorporation Inc, 741 P.2d 846, 848 (Okla. 1987).
} 


\section{VALPARAISO UNIVERSITY LAW REVIEW [Vol. 36}

managers, in the eyes of most courts does not disable. The argument is frequently made in the context of special litigation committees' recommendations that derivative suits not go forward against fellow directors. The "there but for the grace of God go I" motivation that may lurk behind a decision that litigation is not in the corporation's best interests, while real, is not, generally speaking, legally cognizable. Nonetheless, out of an abundance of caution, and also a subliminal recognition of the structural bias problem, most boards staff special litigation committees with new "expansion" directors who can in no way be alleged to have any connection with the wrongdoing alleged and against whom the structural bias argument has less force.

Another universal principle is that if a single decision-maker seeks the protection of the business judgment rule she must, "like Caesar's wife, be above reproach." 40

A sub-species of the conflict of interest species is the dominated director case. Rather than a discernable pecuniary interest, what is alleged is that the director is beholden generally to a controlling shareholder or CEO, thus being disabled by his lack of independence. A plaintiff making such an argument faces an uphill battle. Courts are loathe to find that an otherwise reputable business person is not his or her own person. Courts would rather rely on an identifiable pecuniary interest to ground a finding that a particular decision maker was disabled. Nonetheless, the cases do succeed from time to time. A five person board staffed by outside counsel, inside counsel, and a corporate employee, all of whom were beholden to the controlling shareholder, who occupied the fourth board slot, was found by the Ohio Supreme Court to have been dominated. 41

By contrast, if counsel and other advisers scrub the board clean, removing all inferences of conflicts or of board domination, and then those non-executive, independent directors, convening in executive session, run the decision-making process from start to finish, their decision is entitled not only to business judgment rule protection, but also to heightened business judgment rule protection. ${ }^{42}$ What that means analytically is hard to say, and it may only be a word choice for

* Kahn v. Tremont Corp., 694 A.2d 422, 430 (Del. Ch. 1997) (quoting Lewis v. Fuqua, 502 A.2d 962, 967 (Del. Ch. 1985)).

1 Gries Sports Enter. v. Cleveland Browns Football Co., 496 N.E.2d 959, 968 (Ohio 1986).

12 See, e.g., Ivanhoe P'ship v. Newmont Mining Co., 535 A.2d 1334, 1343 (Del. 1987). 
emphasis. The result though is clear. The decision made will be very nearly unassailable if the rule' $s$ other elements are met.

\section{COMPONENTS OF THE RULE - A RATIONAL BASIS FOR THE DECISION}

Directors could be free of disabling - indeed, all - conflicts or domination, gather voluminous information, digest, and make not only an unwise, but an off-the-wall decision. Under the ALI version, such a decision would not be entitled to business judgment rule protection. A decision to put a man on Mars, or to accept not only a lower but clearly inferior bid for the company, might be judgments lacking a rational basis. ${ }^{43}$

On this score, some judges and commentators say that directors are not liable unless their decision or judgment was manifest folly. Others say that directors' decisions are unassailable unless they amount to a gross abuse of discretion. Those phrasings may be too permissive. By contrast, the statement that "all directorial decisions must have a sound business purpose" goes too far in the other direction.

During deliberations at ALI annual meetings, many members, especially older members, thought that the "rational" basis requirement differed little from a "reasonable" basis. They entreated the ALI reporters to find another phrasing, as they were certain that the rational basis requirement would be an invitation to prolonged litigation. This author, however, has been teaching the ALI business judgment rule to large classes of law students since 1980. Almost without dissent, those students see ample cleavage between the "rational basis" standard and the much more exacting "reasonable basis" standard.

One esteemed commentator, and also no less an authority than exDelaware Chancellor, William Allen, both deny that any rational basis requirement exists, at least as part of the Delaware version of the rule." Professor Lyman Johnson observes that a rational basis standard would lead judges astray, from examining the soundness of the decisionmaking process, to an examination of the decision itself. Chancellor

43 See, e.8., Gimbel v. Signal Cos., Inc., 316 A.2d 599, 610 (Del. Ch.), aff d., 316 A.2d 619 (Del. 1974) ("There are limits on the business judgment rule which fall short of intentional or inferred fraudulent misconduct and which are based simply on gross inadequacy of price."); cf. Paramount Communications, Inc. v. Time Inc., 571 A.2d 1140, 1152 (Del. 1990) (decision to accept clearly inferior bid in merger of equals entitled to business judgment rule protection).

4 See Lyman Johnson, The Modest Business Judgment Rule, 55 Bus. LAw. 625, 632-33 (2000). 


\section{VALPARAISO UNIVERSITY LAW REVIEW [Vol. 36}

Allen reached the same conclusion based on his reading of countless Delaware decisions. 45

\section{COMPONENTS OF THE RULE - UMBRELLA REQUIREMENT (BROODING OMNIPRESENCE) OF GOOD FAITH}

In a transactional setting, an attorney advising a board might run through the rule's elements as a checklist: judgment or decision, absence of disabling conflicts, some care, and a rational basis. She would then do well to pause, raise her head, and sniff - loudly and several times. All good lawyers apply a "smell test." Even if all of the law's formal requirements have been met, if the deal under consideration does not feel right, or smell right, they do not do the deal, or at least they advise postponement until they dig down to the source of their olfactory concern.

In the business judgment rule context, the umbrella requirement of good faith is a surrogate of sorts for a smell test. It also has particular utility in two more delimited areas.

One is when the decision-making process has been infected by illicit motives other than pecuniary conflicts. Revenge, spite, jealousy, or other base motives may be behind a decision. In such a case, lack of good faith would be the proper means by which to attack the decision. ${ }^{46}$

Another is knowing approval of illegal conduct. Directors who approved forgiveness of indebtedness by a political party when the forgiveness was tantamount to an illegal campaign contribution were not entitled to protection, even though they had no personal conflicts and they had a rational basis for the decision made. ${ }^{47}$

15 See In re Caremark Int'l, Inc. Derivative Litig., 698 A.2d 959, $967-68$ (Del. Ch. 1996); cf. Parnes v. Bally Entm't Corp., 722 A.2d 1243, 1246 (Del. 1999) ("The presumptive validity of a business judgment is rebutted in those rare cases where the decision under attack is 'so far beyond the bounds of reasonable judgment that it seems essentially inexplicable on any ground other than bad faith.").

${ }^{46}$ See, e.g., In re RJR Nabisco, Inc. Shareholders Litig., 1989 WL 7036 (Del. Ch. Jan. 31, 1989).

The court stated:

Greed is not the only human emotion that can pull one from the path of propriety; so might hatred, lust, envy, revenge, or . . . shame or pride. Indeed any human emotion may cause a director to place his own interests, preferences or appetites before the welfare of the corporation.

Id. at "15.

17 See Miller v. Am. Tel. \& Tel. Co., 507 F.2d 759 (3d Cir. 1974). 
A recent decision stated that directors who knowingly or deliberately withhold material information from the board in order to mislead shareholders lack good faith. Under such circumstances the shroud of protection otherwise afforded by the business judgment rule would fall to the ground. ${ }^{48}$ Another recent case held that a cryptic and peremptory refusal of a derivative action plaintiff' $s$ demand, in a case of obvious wrongdoing, constituted a lack of good faith. The court could thus look into the merits of demand denial itself. ${ }^{49}$

The good faith requirement is something of a catch-all. It also demonstrates the flexibility of the business judgment rule. For example, in a dominated directors' case, a court could alternatively find that the directors rubber-stamped the decision of a controlling shareholder and made no judgment or decision, that the directors lacked independence, or that the directors lacked the required good faith. In nearly every business judgment rule case, then, judges have a number of "outs," although in their wisdom judges may choose not use them. This is as it should be because, first and foremost, the business judgment rule is a judicial construct, born out of judges' realizations about limitations on their abilities, about conservation of the judicial resource, and about their proper role in business cases.

\section{PRESUMPTION OR PREREQUISITE?}

Delaware courts - and courts in jurisdictions that follow Delaware law - phrase the business judgment rule as a "presumption" that "in making a decision, the directors of a corporation acted on an informed basis and in good faith." 50 In his treatise, the late Professor Ed Cleary found that no concept in the law of evidence was more slippery than the concept of presumption, save perhaps the concept of burden of proof. Professor Cleary found no less than eight meanings courts have given to "presumption." 51

\footnotetext{
4 Potter v. Pholad, 560 N.E.2d 388, 395 (Minn. Ct. App. 1997) (applying Delaware law from Emerald Partners v. Berlin, 1995 WL 600881, at 7 (Del. Ch. September 22, 1995)).

19 Harhen v. Brown, 710 N.E.2d 224, 234-36 (Mass. Ct. App.), rev'd, 730 N.E.2d 859 (Mass. 2000).

so See supra notes 16-19 and accompanying text (discussing Aronson v. Lewis, 473 A.2d 805 (Del. 1984)).

31 EDWARD W. Cleary, MCCORMICK ON EVIDENCE $\$ 342$ (3d ed. 1984).
} 


\section{VALPARAISO UNIVERSITY LAW REVIEW [Vol. 36}

The most frequent understanding of presumption is the Thayerian, or "bursting bubble," theory of presumptions. ${ }^{52}$ That is to say, a party's proof of circumstances A, B, and C (here, a judgment or decision, by duly elected directors, who exercised some care) leads to a presumption of the ultimate fact, $D$ (here, that reasonable care was in fact exercised). If the opposing party can poke a hole in the foundational facts (conflict of interest, were woefully under-informed, and so on), then the bubble bursts and the presumption of the ultimate fact dissipates or, indeed, evaporates altogether. This theory of presumption predominates in American law and is the version the Federal Rules of Evidence adopted. ${ }^{53}$

When Delaware and other courts use the language of presumption, they seem blissfully unaware of what the law of evidence teaches us about presumptions. Perhaps they are articulating some other nonThayerian view of presumption when, in a case or two, they have referred to the business judgment rule as a "powerful presumption." 54

I doubt it. Instead I think that Delaware jurists have given the bursting bubble theory very little thought. And, that lack of deliberation is of no moment in Delaware. Delaware courts require more than a pin prick - indeed, much, much more - before finding that the presumption of due care set up by application of the rule vanishes.

For example, in In re Walt Disney Company Derivative Litigation, ${ }^{55}$ the Delaware chancellor reviewed the payment of a $\$ 140$ million severance package to a crony of CEO Michael Eisner who had served less than a year as corporate president and who had demonstrated a singular lack of accomplishment (many would say outright malfeasance) in the position. Nonetheless, the directors approved a "no fault" termination, triggering payment of the severance. The directors who approved included Eisner, three corporate officers beholden to Eisner, the principal of the grammar school Eisner's children attended, the president of the university Eisner's children attended, Eisner's personal architect, and Eisner's personal attorney. If ever a plaintiff pricked and burst a bubble on lack-ofindependence grounds, the plaintiffs did in Disney. Nonetheless, the

52 James Bradley Thayer, A PRelimmary Treatise ON EVIdence at the COMMON LaW 314 (1898). Thayer was an eminent Harvard Law School lecturer on evidence and other subjects around the turn of the twentieth century.

53 See FED. R. EVID. 301; CLEARY, supra note 51, at 974-75.

st See, e.g., Cede \& Co. v. Technicolor, Inc., 634 A.2d 345, 361 (Del. Ch. 1993).

55731 A.2d 342 (Del. Ch. 1998), rev'd on other grounds, Brehm v. Eisner, 746 A.2d 244 (Del. 2000). 
Delaware Court refused to review the merits of the no fault termination decision, applying the business judgment rule.

Delaware courts' lack of deliberation on the use and misuse of presumptions may be of little significance in Delaware but could affect outcomes elsewhere. The courts of many states, including Indiana, look to Delaware case law in processing corporate law cases. ${ }^{56}$ Blending the Delaware business judgment rule with the accepted wisdom about presumptions, other state courts could come to a result opposite that which Delaware courts would reach, holding corporate directors over for trial on breach of duty of care allegations.

The American Law Institute states its version of the rule as a safe harbor rather than a presumption. Although the ALI version has been criticized as a movement from "presumption to prerequisite," 57 the ALI version offers greater protection and clarity than the presumption formulation of the business judgment rule because the ALI version requires a greater quantum of proof by directors.

\section{PARTICULAR APPLICATIONS OF THE RULE - Dismissal OF DERIVATIVE LITIGATION}

In 1979, both the New York Court of Appeals and the United States Supreme Court dusted off a few older precedents, finding in them support for the proposition that a board of directors has power to terminate derivative litigation bought by a shareholder as not in the "corporation's best interests." 58 In theory, the concept is sound. Just as a natural person may do, a corporation should be able to decide not to stand on legal rights it may have. The difficulty is how, as a fictional being, the corporation can find its voice for making that decision. This difficulty is compounded in the typical derivative action because the defendants are some of the corporate officers and directors, a subgroup of the group that ordinarily would manage the corporation's business and affairs and be its voice for determining whether or not to pursue an action, namely, the corporation' s board of directors.

\footnotetext{
S6 See supra note 19 (discussing Indiana business judgment rule cases relying on leading Delaware precedent, Aronson 0 . Lewis). But see infra notes 74-75 and accompanying text (explaining that Indiana courts may not look to Delaware precedent in takeover area).

57 See, e.g., Camey, supra note 13, at 273.

s8 Burks v. Lasker, 441 U.S. 471 (1979) (finding no federal obstacle in the Investment Company Act of 1940 if state law, pursuant to which a mutual fund had been organized, authorized the practice); Auerbach v. Bennett, 393 N.E.2d 994 (N.Y. 1979).
} 


\section{VALPARAISO UNIVERSITY LAWREVIEW [Vol. 36}

The manner in which the potential conflict of interest came to be reconciled was through the use of the special litigation committee, or SLC. If a shareholder brought colorable claims against some of the directors, counsel would first instruct the board of directors to amend the corporation's bylaws, increasing the number of directors. Second, the board would appoint two or three "expansion" directors to the positions so created who could have had no possible connection to the alleged wrongdoing and who, in addition, often would be "purer than the driven snow." Third, the full board would delegate to the committee all the board's power to deal with the pending action or shareholder demand that an action be brought. ${ }^{59}$ Once convened, the SLC would then hire an independent law firm to conduct a factual investigation of the shareholder's allegations and to research the applicable law. The firm would report periodically to the SLC and involve SLC members in the investigation, at least at crucial stages.

In the typical scenario, eight or ten months later the SLC will promulgate a report, which it files with the court. Appended to the report will be a voluminous report of the investigation and a legal memorandum. By motion for summary judgment, the SLC will then ask the court to dismiss the shareholder action as having been found by the SLC "not in the corporation' s best interests." Because the SLC has made a judgment or decision, exercised some care in making that decision, demonstrated freedom from conflicts of interest, and set forth a very rational basis for the decision made, the SLC will contend that its decision is entitled to business judgment rule protection.

The SLC device is accepted everywhere courts have encountered it. Instead, the frontier is what sort of deference, and what sort of review, courts should give to SLC reports and recommendations. No less than five positions have been adumbrated.

In several jurisdictions, courts afford the SLC recommendation full business judgment rule protection. That is, if the SLC members offer an affidavit or similar proof establishing the elements of the rule, the court never reviews the merits of the SLC recommendation to dismiss the action. This is the position adopted by New York in the early case of Auerbach v. Bennett.60

${ }^{59}$ See, e.8., BRANSON, supra note 1, $\$ \$$ 11.31-11.32.

${ }^{60} 393$ N.E.2d 994 (N.Y. 1979); see also, e.g., Hirsch v. Jones Intercable, Inc., 984 P.2d 629, 637. 38 (Col. 1999); Gray v. Manhattan Med. Ctr., 18 P.3d 291, 297 (Kan. App. Ct. 2001); Lewis v. 
Other courts, most notably in Delaware, have stated that a decision to dismiss litigation is qualitatively different from the types of decisions ordinarily given business judgment rule protection, such as directors' decisions to make an acquisition or build a new plant. Courts have no expertise in the latter but they do have expertise - lots of it in fact - on the issue of whether litigation should proceed or be dismissed.61

In their discretion, Delaware trial judges (chancellors) may review the merits of a SLC recommendation, but only in demand excused cases. ${ }^{62}$ Under a North Carolina precedent, in their discretion, trial courts may review the merits of a recommendation in all cases, demand refused or demand excused.63 The Massachusetts precedent requires trial judges to conduct at least a "smell test" as to the merits of SLC recommendations in all cases. ${ }^{64}$ Last of all, the ALI schematic, adopted in toto by the Supreme Court of Pennsylvania, contemplates discretionary view of a SLC recommendation when directors have been accused of duty of loyalty violations but non-review when a SLC recommends that duty of care allegations be dismissed. ${ }^{65}$

\section{INDIANA'S BUSINESS JUDGMENT RULE}

Indiana has codified its choice legislatively.66 It opts for the Auerbach v. Bennett standard of non-review. The legislation provides that "[i]f the [SLC] committee determines that pursuit of a right or remedy through a derivative proceeding or otherwise is not in the best interest of the corporation, the merits of that determination shall be presumed to be conclusive...." A shareholder may challenge the recommendation only by demonstrating that "[t]he committee was not 'disinterested" or that "[ $t$ ]he committee's determination was not made after an investigation conducted in good faith." In other words, a shareholder in an Indiana

Boyd, 838 S.W.2d 215, 224 (Tenn. Ct. App. 1992). Many of the early cases were educated Erie guesses by federal courts about what they thought state high courts would do. See, e.g., Gaines v. Houghton, 645 F.2d 761 (9th Cir. 1981) (applying California law), cert. denied, 454 U.S. 1145 (1982); Lewis v. Anderson, 615 F.2d 778 (9th Cir. 1979) (applying California law); Genzer v. Cunningham, 498 F. Supp. 682 (E.D. Mich. 1980) (applying Michigan law).

61 Zapata Corp. v. Maldonado, 430 A.2d 779, 787-89 (Del. 1980).

62 Such a review is referred to as the "Zapata second step," after the Delaware case by that name. See supra note 61.

63 Alford v. Shaw, 358 S.E.2d 323 (N.C. 1987).

6t Houle v. Low, 556 N.E.2d 51, 56-57 (Mass. 1990). The Supreme Court of New Jersey followed Houle in In re PSE \& G Shareholder Litig., 718 A.2d 254, 260 (N.J. 1998).

os See Cuker v. Mikalauskas, 692 A.2d 1042, 1049 (Pa. 1997).

6 IND. CODE \& 23-1-32-4 (1989). 


\section{0 VALPARAISO UNIVERSITY LAWREVIEW [Vol. 36}

corporation may only challenge SLC findings on business judgment rule grounds and not on the merits of the SLC recommendation itself.

In Cutshall v. Barker, ${ }^{67}$ the Indiana Court of Appeals reviewed a SLC recommendation emanating from procedures scripted in accordance with the Indiana statute. The trial court afforded the SLC determination business judgment rule protection and dismissed the plaintiff's claims in their entirety. The appellate court did not admit even of the possibility of a review on the merits (or a so-called Zapata second step), citing and following Auerbach $v$. Bennett. In so doing, the court tied up a few loose ends before affirming.

The Cutshall court held that a law firm which represented both the corporation and the SLC did not lack the independence the cases require. Because the law firm had been hired in both capacities after suit had been filed, the law firm had no conceivable connection with the wrongdoing alleged. Under the SLC precedents, the law firm had the independence required.

The law firm did not do such a great job. The SLC did not swear any witnesses and did not transcribe any witness interviews. Most law firms would advise a SLC to do both. Nonetheless, the Cutshall court found the investigation to have been conducted in "good faith," as the Indiana statute and commentary thereto require. ${ }^{68}$

Indiana's stance and the application of the business judgment rule in Indiana to SLC recommendations are set firmly in place both by legislation and an authoritative Court of Appeals decision.

\section{PARTICULAR APPLICATIONS OF THE RULE - REVIEW OF ADOPTION OF TAKEOVER DEFENSES}

Another type of decision that differs from typical investment or management decisions, such as whether to develop a new product or modernize a new plant, is the board's decision to adopt takeover defenses or to prefer one competing bidder for a company over other bidders. Here again, directors should not necessarily have exclusive jurisdiction. Shareholders should have more of a say with regard to whether an offer for the company should be entertained or one offer

67733 N.E.2d 973 (Ind. Ct. App. 2000).

61 Id. at $981-82$ (construing IND. CODE \& 23-1-32-4(c) and the Official Comment thereto). 
preferred over another, as opposed to a decision to modernize a plant. At a minimum, jurisdiction should be shared or concurrent.

So, again, courts began to use the business judgment rule as the yardstick. But, as with the review of SLC recommendations to dismiss derivative actions, courts added on refinements to the business judgment rule in order to factor in the differing nature of the judgment or decision under review. Once again, Delaware courts lead the way.

The first refinement of the business judgment rule came in Unocal Corp. v. Mesa Petroleum C0.69 which sets out a "response phase" business judgment rule dealing with directors' responses to takeover bids. To receive business judgment rule protection, the directors adopting a takeover defense must also have inquired whether a realistic "danger to corporate policy and effectiveness existed because of another person' $s$ stock ownership." Any defensive measure taken, then, "must be reasonable in relation to the threat posed."70 In applying these added elements, courts are to apply "enhanced scrutiny" to actions directors have taken, in part because of "the omnipresent specter that [in the takeover area] a board may be acting primarily in its own interests." 1

Shamrock Holdings, Inc. v. Polaroid Corp. 72 illustrates what has come to be known as the "proportionality" add-on to the business judgment rule. Potential target, Polaroid, stalled a meeting with a friendly acquirer of shares (Roy Disney) while it installed an employee stock ownership plan, or ESOP, as a defensive measure. Without even knowing precisely what the threat posed was, the directors adopted an expensive and drastic measure. The Delaware vice-chancellor found that the Polaroid directors had neither adequately informed themselves, as the business judgment rule requires, nor "undertake[n] the [proportionality] analysis mandated by Unocal Corp." and the refined business judgment rule that case promulgates for the takeover area.

A third business judgment rule comes into play in the "auction phase" of a takeover. In Revlon, Inc. v. MacAndrews \& Forbes Holdings, Inc., ${ }^{73}$ the Delaware Supreme Court held that when it has become inevitable that a company will be sold or broken up, the "directors' role changed from defenders of the corporate bastion to auctioneers charged

\footnotetext{
69493 A.2d 946, 954 (Del. 1985).

70 Id. at 955.

$\pi$ ld. at 954 .

7559 A.2d 257, 271 (Del Ch. 1989).

> 506 A.2d 173 (Del. 1986).
} 


\section{VALPARAISO UNIVERSITY LAWREVIEW [Vol. 36}

with getting the best price for the stockholders at a sale of the company." Under Delaware precedent, in the auction phase, any defensive measures undertaken by directors must be a "rationally related benefit to the shareholders" in order to receive business judgment rule protection.

Thereafter, the Delaware takeover jurisprudence takes several twists and turns, refining further the application of the business judgment rule to the takeover area. All those twists and turns are beyond the scope of this Article.

Suffice it to say that business interests in Indiana did not care for the developing Delaware jurisprudence. They lobbied for and had the General Assembly add to the statute's duty of care provision the following subsection, which is quite unlike anything in any other United States jurisdiction:

[T] he general assembly intends to reaffirm certain of ... corporate governance rules to ensure that directors of Indiana corporations, in exercising their business judgment, are not required to approve a proposed corporate action if the directors in good faith determine ... that such action is not in the best interests of the corporation. In making such determination, directors are not required to consider the effects of a proposed corporate action on any particular corporate constituent group [i.e., shareholders] or interest as dominant or controlling. ${ }^{74}$

Just in case their intention to negate any application of either Unocal or Revlon in Indiana was not crystal clear, legislators added in the statute itself the following:

Certain judicial decisions in Delaware and other jurisdictions, which might otherwise be looked to for guidance in interpreting Indiana corporate law, including decisions relating to potential change of control transactions that impose a different or higher degree of scrutiny on actions taken by directors in response to a proposed acquisition of control of the

${ }^{24}$ IND. CODE \& 23-1-35-1(f) (1989). 
corporation, are inconsistent with the proper application of the business judgment rule under this article.75

Ergo, no Unocal, no Revlon, no enhanced scrutiny, no proportionality add-on, and no duty to conduct an auction exist in Indiana. Under the provision enacted in Indiana, if directors adopt a wrong-headed, scorched earth defense of some sort - on incomplete news that someone may be acquiring a larger holding of the corporation's shares - those directors, their ignorance, and their over-reaction will be protected from judicial scrutiny by the Indiana version of the business judgment rule. The provision is a permanent solution to what was a temporary phenomenon (the takeover boom of the 1980s) and should be repealed.

\section{DOES INDIANA NEED A BUSINESS JUDGMENT RULE AT ALL?}

The Indiana General Assembly has done such a thorough job of protecting Indiana directors on all fronts, and not just in the takeover area, that at first blush Indiana may not even have a business judgment rule. The reason is that Indiana is one of three or so states that have adopted a "warm heart, empty head" standard of liability with which to measure director conduct. In Indiana, "[a] director is not liable for any action taken as a director, or any failure to take action, unless ... [t]he breach or failure to perform constitutes wilful misconduct or recklessness." 76 As long as directors had warm and fuzzy feelings in their chests when they took action, no matter how ill conceived their inactions or how empty their heads were, they will not be liable. Who needs a business judgment rule when the standard of liability is so forgiving?

The answer is that many corporate law actions are fought out at the temporary restraining order and preliminary injunction stages of litigation. Shareholder plaintiffs seek to enjoin transactions or forestall meetings at which votes will be taken. The business judgment rule shields transactions as well as individual directors from full judicial scrutiny. The business judgment rule therefore remains important even though a legislative enactment has, by and large, removed the issue of director liability from the equation.

${ }^{76}$ Id. \$ 23-1-35-1(e) (1989). 


\section{VALPARAISO UNIVERSITY LAWREVIEW [Vol. 36}

\section{CONCLUSION}

Indiana is not alone in enacting a permanent solution to temporary problems such as the takeover boom and the director-officer liability crisis of the mid-1980s. Since then, however, courts in Delaware have worked out judicial solutions for many of the perceived problems Indiana faced.7 As a legal scholar, I am no apologist for, and at times have been critical of, the Delaware corporate law regime.78 But perhaps Indiana should repeal some of its enactments so that its courts could benefit from the rich Delaware takeover jurisprudence.

That then is the business judgment rule - a rule that is not a rule. It is a great law school teaching tool. In the non-academic world, properly applied, the rule permits courts to accord to boards of directors the proper amount of deference to board decisions. Last of all, the rule provides a schematic for any advisor counseling any collegial group, and not just a board of directors, to reach a judgment or decision that in all likelihood will be a sound one.

\footnotetext{
$\pi$ For example, in Paramount Communications, Inc. v. Time, Inc., 571 A.2d 1140 (Del. 1990), the court carved out a large exception to the auction duties outlined in Reolon. In a merger of equals, a target corporation could "just say no" to a third-party takeover bid even if it were at a superior price and, if challenged in court, that "just say no" response would be reviewed under the business judgment rule. Id. at 1152-53.

$\pi$ See, e.g., Douglas M. Branson, Indeteminacy: The Final Ingredient in an Interest Group Analysis of Conporate Law, 43 VAND. L. REv. 85 (1990).
} 